\title{
DEFINING THE ROLE ADJUSTMENT PROFILE OF LEARNERS AND INSTRUCTORS ONLINE
}

\author{
Martha Burkle
}

Natural Sciences and Engineering Research Council of Canada / Informatics Circle of Research Excellence

Athabasca University

Martha Cleveland-Innes

Athabasca University

\begin{abstract}
The purpose of this research was to analyze the experience of post-secondary first time online students combining time spent in the classroom-workshop with online course access, and their interactions with instructors. In the following discussion, and following the Cleveland et al. [1] model, a comparison between the categories 'student's role adjustment' and 'instructors' role' is presented.
\end{abstract}

\section{KEYWORDS}

online learning, e-readiness, learner competencies

\section{INTRODUCTION}

Recent research in online learning [1] identifies five areas of adjustment for students experience becoming a competent online learner: virtual interaction, self-identity, instructor role, course design and technology. This paper is about the first, second and third of these areas and about the importance of analyzing the role that students and instructors play when they interact online. Competencies categories are used to examine research findings from a research project carried out in Canada that explores the different roles played by students and instructors interacting online. Research findings show that instructors and students must adjust by developing new competencies and by integrating this competence into new roles appropriate to online teaching and learning.

\section{LITERATURE REVIEW}

The number of post-secondary institutions offering courses online has increased exponentially during the last decade. Recent evaluations of student enrolments demonstrate growth at rates faster than for the overall student body." [2] Two important elements must be addressed as institutions make radical changes to allow curricula to be accessed online: students' engagement in an online environment, and the transformation of instructors' role.

To engage in this online environment, learners develop new skills required to be proficient online, and will modify past learning actions to fit the online environment. Details of this adjustment process for learners to online delivery is still under explored; "there is also a need for better understanding of students' adaptation to online learning over time." [3].

This process of adjustment to the role of online learner may be further understood by looking at the structure of the online pedagogical environment of an online community of inquiry [4] and the tenets of Blau \& Goodman role theory [5] and how role change occurs [6]. Furthermore, the integration of new 
actions into one's role inventory [7] takes place within a context [8] and through an intricate process of role taking, role exploration and role making [5]. As the context of teaching and learning in online environments is radically different from traditional classroom structures it can act as a catalyst for role adjustment for individual students moving online.

The paper presents research which demonstrates changes learners and instructors experience as they adjust to online delivery. These changes not only affect the immediate learning experience, but also provide competencies which may transfer to learning at the workplace. Recommendations for e-readiness future areas of research are discussed.

\section{A. Analyzing online role adjustment}

The term role within the community of inquiry model is used as a sociological construct, defined as a collection of behavioral requirements associated with a certain social position in a group, organization or society [9]. At its most general level, role expectations are determined by the social structure. Individuals who engage in the role are guided, through a process of socialization, to appropriate role performance. Socialization then refers to the "process by which people learn the characteristics of their group ... (and) the attitudes, values and actions thought appropriate for them" [10].

A further analysis of 'role making' identifies a process where individuals construct aspects of the role with their own individual meanings and satisfying behaviors attached. This occurs under social conditions where such individual autonomy is allowed. It also occurs where role models are not readily available, and construction of the role is required. Such is the case for becoming an online learner. An adjustment from the more generalized role of learner needs to take place when the learning space is not a physical one, but virtual. The responsibilities and requirements of working online are not readily apparent to those new to the role. The transition to, and adjustment in, the role of online learner is part of the current social climate in online learning. While maintaining the usual expectations and privileges attached to the role of learner, online learners then add some or all of these competencies:

- e-Readiness is defined as knowledge about, skill with, and acceptance of, Internet technology

- Increased time on task and study management due to required learner self-direction

- new modes and channels of communication with instructors, peers, and course administrators

- $\quad$ synchronous and asynchronous approaches to learning

An online community of inquiry is a distinctive personal and public search for meaning and understanding. The competencies and role change listed above are required in the context of an online community of inquiry. Learners assume greater responsibility for and control over their learning. As McLuhan observed, "each form of transport not only carries, but translates and transforms the sender, the receiver and the message" [11]. An asynchronous and collaborative learning community necessitates the adoption of personal responsibility and shared control. This goes to the heart of an online learning community and represents a significant shift from the information transmission of the lecture hall and the passive role of students, to a more interactive model, where students assume responsibility of their own learning. Thus, online learning communities demand role adjustments. This brings another need: to understand changes in competencies, responsibilities, and roles.

Differences in the required activities for online learning result in new, required expectations and behaviors for learners, in comparison to place-based learning. These new activities cluster into a pattern that is seen as the role of online learner. The term role refers to the expected and generally accepted ways of behaving, acting and interacting [12]. Taking on a role [e.g. instructor, tutor, learner] involves learning what the expected behaviors are through a process of observation and trial and error attempts at the role [13]. While the adoption and enactment of social roles is a standard, commonplace element of everyday experience, becoming an online learner has a unique characteristic. For many learners, role models for learning the required and expected activities are not present until one is already engaged in an online course [14]. 
The experience of 'role acquisition' among instructors and learners interacting online is also part of individuation in the experience of working in a new space. Each online learner engages in the experience of learning online and the process of role taking, and role making occurs concurrently within the learning experience. From the perspective of the individual, learning online requires the development of competencies in the role of 'online learner'. As a new social role, the pathway to competence will occur over time as the role becomes prevalent and normalized. In this early stage, online communities will contribute to the socialization process for those engaging in this new role. The result is a new role and a new identity for learners.

\section{B. Learning online: The Net Generation}

The Millenials, or the Net Generation, are controversial terms that were first used by Prensky in 2001 [15]. In his opinion, the Net Generation includes all those young students to whom computer games, email, the Internet, cell phones and instant messaging are integral parts of their lives $[15,16,17]$. Digital natives are those who have always known the Internet as their digital environment. Others have called this new generation of students the Net Gen, where Net refers to either networking or Internet use. The Digital natives or Net Gen-ers were born at a time when computers were an important part of the dynamics of a home, and where the Internet had become an integral part of daily activities.

For those authors who sustain the Net Gen concept, the average college graduate has spent today less than 5,000 hours of their lives reading, but over 10,000 hours playing video games. As a result of this ubiquitous technology, many social scientists sustain that today's students in North America think and process information differently than their predecessors. Even more so, their entire system of beliefs and values is different from those in previous generations, and these differences usually go further and deeper that most educators recognize.

Some argue that even if the digital natives have slight differences in speech and social interactions, they are fluent in digital communication forms that are prevalent in the new land [18, 19]. Oblinger refers to the 'Millenials' in this way: "They gravitate toward group activity and social networking; they identify with their parents' values and feel close to their parents; they spend more time doing homework and housework and less time watching TV, they believe it's cool to be smart, they are fascinated by new technologies; they are racially and ethnically diverse..." [20].

Academic colleagues from different countries have begun to consider whether students around the world have similar experiences to those in North America. For example, Oliver and Goerke [21] developed research on undergraduate students in Australia to find out whether their students confirm these assertions. They found that "ownership of laptops, mobile phones and music devices appears to be growing rapidly among this group, along with their use of tools such as instant messaging, blogs and podcasts." Another example of this is the work done by Creanor and his research team in 2011 and published as the Lex (Learner Experience of E-learning) Report [22]. A total of twenty-two interviews and six focus groups were conducted that evaluated students' experiences with e-learning in the UK. Findings of the report include the fact that learners involved in the research tended to be highly skilled networkers and often use technology to obtain support when needed.

The changes that today's students bring with them when they learn online-with some of these changes evident even in their brain structures, according to Tapscott [23] — creates an urgent call to understanding the different ways they learn. In turn, this fact calls for a change in the way institutions provide educational opportunities to learners. It is time to radically change the way teaching takes place, and the way instructors approach their teaching practices to transform these into more student-centered environments.

In the next section of this article, the new role of the instructor that online learning has made possible, will be analysed. Elements of the new pedagogical model of learning supported by technology, where the instructor has become a facilitator of knowledge development and is no longer the 'knowledge holder' $[24,25,26,27,28]$, will be examined. 


\section{Teaching online: the changing role of the instructor}

The transformation of the instructor from a knowledge source to a facilitator was first proposed by Laurillard in 2002 [29] as a conversational framework for the evolution of learning. In order to enable the evaluation of the effectiveness of learning, Laurillard identifies the key elements of the process: discussion, interaction, adaptation, and reflection (on the student's performance by instructor and student). Laurillard believes that this framework can be applied to the evaluation of technologies in learning. In fact, one of the main goals for the use of teaching and learning technologies should be to provide student-centered situations where instructors facilitate access to content in a horizontal, sharing environment where students learn as much from the course theoretical content as from their peers.

Another analysis of the changing role of the instructor was made by Sfard [30] who examined faculty's changing role from a knowledge holder into a facilitator through the use of information technologies. He identifies two teaching and learning models: the 'acquisition model' and the 'participation model'. In the acquisition model, the role of the instructor is to deliver, suggest, and clarify knowledge and concepts. With the acquisition model, the focus of learning goals is on acquiring pre-specified knowledge and on developing understanding of predetermined concepts.

In the participation model, instructors are seen as facilitators, mentors, expert participants, and guardians of practice/discourse. With the participation model, the focus of learning activities is on becoming a member of a community of practice, learning from the community but also contributing to it. The collaboration (transformation) framework emphasises individual thinking and construction of meaning. Teaching with this approach is more tentative, flexible, and experimental; hence it is student-centered. In this context, a community of learners will improve learning through their interaction [31,32].

Collis and Moonen [33] and Sloman [34] completed the comparison of the two models by stating that a pedagogical theory means little if instructors do not apply it, and that technological resources have no value if they are not used. In fact, the authors stress the fact that the number of instructors who want to apply innovation models to their teaching is still very small.

Holley and Haynes [35] maintain that the changing role of the instructor is most visible in the ongoing disappearance of individual or small group teaching, and in the attempts to change the nature of contact time away from delivery of information towards more active participation. The development and implementation of widely accessible communication and information technologies has been a key driving force in the move towards the adoption of social constructivism as a guiding principle in Higher Education Institutions HEIs [29]. In other words, this change has resulted in a change in the role of the instructor from the 'sage of the stage', where transmissive, didactic learning took place, to the 'guide on the side, where more student-centered learning takes place [36].

On a similar discourse, Sloman [34] supports the idea that the 'acquisition model' could be associated with behaviourist theory, while the 'participation model' is related to a constructivist approach. This assumption is based on the fact that in the transmission model, a teacher (lecturer or instructor) can pass on a fixed body of information and the student or learner interacts with a pre-packed content, while the transformation framework implies individual thinking and constructing of meaning.

At the intersection of these multiple suggestions is the need for an online model that provides direction for instructors, and directions that manage the technology and support the new role of the online learner. This is the case whether the instructor is working in a blended or online environment. In an online community of inquiry, instructors must ensure they are present, and that students participate and are present. Both students and instructors adjust to identify with the community, communicate purposefully, and develop inter-personal relationships.

\section{RESEARCH METHODOLOGY}

In this section of the paper data collected in a post-secondary institution in Alberta, Canada, is analyzed following the model proposed by Cleveland-Innes et al in 2009 [1]. Research methodologies are examined and research findings are discussed. 


\section{A. The Research project}

This study analyzes the possibilities of using online/mobile technologies for hands-on training. In September 2011, and with funding from the province, a polytechnic institution in Alberta redesigned a number of courses for one of its Apprentice programs so that students will have access to course content online. The decision was based on the following institution's needs and expectations:

a. Facilitate a flexible environment where registered students could learn at their own pace.

b. Allow students to combine work and study in an engaging environment.

c. Support collaborative learning among students, by promoting critical thinking in a challenging and unique environment.

d. Reduce classroom time for student apprentices.

e. Analyze student expectations of learning online

f. Explore the impact of mobile content on students' learning

g. Learn about online course efficiency and course engaging capacity.

The online course was designed with the goal of combining access to learning materials through an LMS (Learning Management System), with workshop (lab) hours. Students will learn the subject matter, complete quizzes and short tests online, and then will attend lab hours on campus to practice what they studied online. At the same time, and in parallel to their students, instructors will interact with students by e-mail (while they were completing quizzes and tests) and will be at the lab to be sure students were able to solve problems and to interact properly with the available tools.

\section{B. Research Sample}

Students involved in this research project were registered in two different courses within two academic programs. Each of these courses was designed into a blended format that combined $70 \%$ of course content (subject theory) taught online and 30\% of course content (practical skills) taught in the lab (workshop). Twenty three online surveys were distributed and answered by students registered between November and December 2010. The survey applied comprised five different sections. Section one intended to obtain information on students' demographics and their previous experience with online learning. Section two was oriented to gather students' opinions with regard to learning goals and course usability. In section three students were asked about their previous experience with online learning and their learning management strategies. Section four gathered information on instructor-student and student-student interaction, through the use of e-mail or the online discussion forums available in the course. At the end of the survey, students had an opportunity to write their personal comments in an open space.

\section{Data collection}

Research instruments were approved by the polytechnic internal Ethics Committee. Survey design included questions regarding students' perspectives about learning online. Questions in the survey were compared with an internal evaluation tool called 'Student instructional Report'-SIR, designed by ETS (Education Transit Systems), which goal is to evaluate students' opinions on instructors' performance. The survey was anonymous, and had a total of 24 questions, some of which were measured on a Likert scale. After the survey was completed, students were invited to participate in a Focus Group to follow up on the information retrieved. Students' participation in the focus group was on a volunteer basis. Information gathered from the Focus Groups was compared with responses obtained from the survey.

At the end of the course, after the students were surveyed and the Focus Groups took place, a series of interviews with instructors were organized. For these interviews, a question guide was followed and the researcher facilitated an open and free space for instructors to share their experiences of teaching online.

\section{Data analysis}

In order to analyze the data obtained from the surveys, the focus groups, and the interviews, a cross reference analysis was applied. What students answered in the survey questionnaire was then compared with open questions led by the researcher during the focus group sessions. A continuous reference to 
other research previously done on the topic served as a guide to perform the data analysis.

\section{RESEARCH FINDINGS}

For the purpose of this paper, research findings were organized following the five categories in the survey (Student's experience with online learning, learning goals and course use, students' management of learning process, instructor- students interaction, and instructor's perception of role change) to provide a clear and straightforward analysis. After findings in these categories were examined, a comparison between these and the Cleveland et al [1] model was used to explore the adjustment online students make.

\section{A. Students' experience with online learning}

The first multiple choice question in the survey was related to students' previous experiences with online learning environments. A good number of learners (41.4\%) had experience using the Internet, but only three of the students in the research sample had previously taken an online course. A related follow-up open question during students' focus groups showed that even if students were not familiar with the use of computers for learning, they were extremely enthusiastic about accessing course materials online. In their own words: "Having access to the course materials anytime, anywhere, I was able to learn at my own pace, without needing to wait to receive coaching from my instructor."

Another interesting finding from this research was that motivation (understood as student engagement) was an important issue for students using the LMS to access course content online. Motivation was determined to be the factor that helped the learners engage in self-learning strategies (such as looking for extra information to complement an assignment). Student participants in this research believed that their instructors encouraged their learning everywhere, breaking the limits of the classroom.

\begin{tabular}{|lr}
\hline \multicolumn{2}{|c}{ Table 1. Student's experience with onlin } \\
First time students learn online & $78.6 \%$ \\
Have taken a blended course before & $14.3 \%$ \\
$\begin{array}{l}\text { Have taken more than one course } \\
\text { online before }\end{array}$ & $7.1 \%$ \\
\hline
\end{tabular}

Table 1. Student's experience with online learning

\section{B. Learning goals and course use capacity}

The purpose of the next section in the survey was to provide feedback to the course development team (Instructors, IDs, Editors, Multimedia, etc.) regarding the course's goals and use capacity. Using a likert scale, students were asked four closed-ended questions and one open-ended question, where they were able to provide further comments. Responses showed that students felt the course goals were clearly stated in the LMS. $15.4 \%$ stated the goal was very clear, $30.8 \%$ stated the goal was clear, and for $38.5 \%$ the stated goal was moderately clear. In the framework of using an online tool to learn, students felt that stating the course goals was very important. These student responses should give some feedback to course developers on improved course design clarity in the future.

Regarding the course navigation, there was an even distribution between students who found the moderately easy to navigate (38.5\%), easy (15.4\%), and difficult $(23.1 \%)$. One student found the course 'somewhat easy'.

An important question was targeted to receive feedback on students' opinions regarding the function of links to websites, videos, PDF documents, etc. Only one student answered that all the links worked 'perfectly'. One other student stated they worked fine, and five students said links worked 'fine most of 
the time'. One student commented that the quizzes did not work well all of the time, and another student stated that they needed more information that was not available in the LMS.

Students' opinions on stated learning goals, course navigation and the function of course links should be taken into consideration in future course development for apprentices. Issues of clarity of course goals should be reviewed by the instructor and the instructional designer before the course goes online.

\begin{tabular}{|ll|}
\hline Table 2. Student evaluation of clarity regarding course goals \\
Very clear & $15.4 \%$ \\
Clear & $30.8 \%$ \\
Moderately clear & $38.5 \%$ \\
Somewhat clear & $7.7 \%$ \\
Not clear at all & $7.7 \%$ \\
\hline
\end{tabular}

Table 2. Student evaluation of clarity regarding course goals

\begin{tabular}{|lc|}
\hline \multicolumn{2}{|c|}{ Table 3. Student evaluation of ease of navigation } \\
Very easy & $15.4 \%$ \\
Easy & $15.4 \%$ \\
Moderately easy & $38.5 \%$ \\
Somewhat easy & $7.7 \%$ \\
Difficult & $23.1 \%$ \\
\hline
\end{tabular}

Table 3. Student evaluation of ease of navigation

\section{Students' management of learning process}

The next section in the survey was oriented to obtain information regarding students' experience as online learners, and their time management strategies. Using a likert scale students were asked six questions to evaluate these items. The first question asked students how difficult the course was for them. None of the students stated the course was very difficult, while six indicated it was somewhat difficult. Seven students considered the level of difficulty as about right, and one student stated that the course was somewhat elementary.

\begin{tabular}{|ll|}
\hline \multicolumn{2}{|c|}{ Table 4. Student evaluation of online course level of } \\
difficulty
\end{tabular}

Table 4. Student evaluation of online course level of difficulty

Regarding students' time management and workloads, half of the surveyed students (50\%) stated the online capability of the course helped them to manage their time more effectively 'most of the time'. $37.5 \%$ of the students reported they sometimes managed their time effectively, and $14.3 \%$ of the students felt they always managed their time effectively always. 


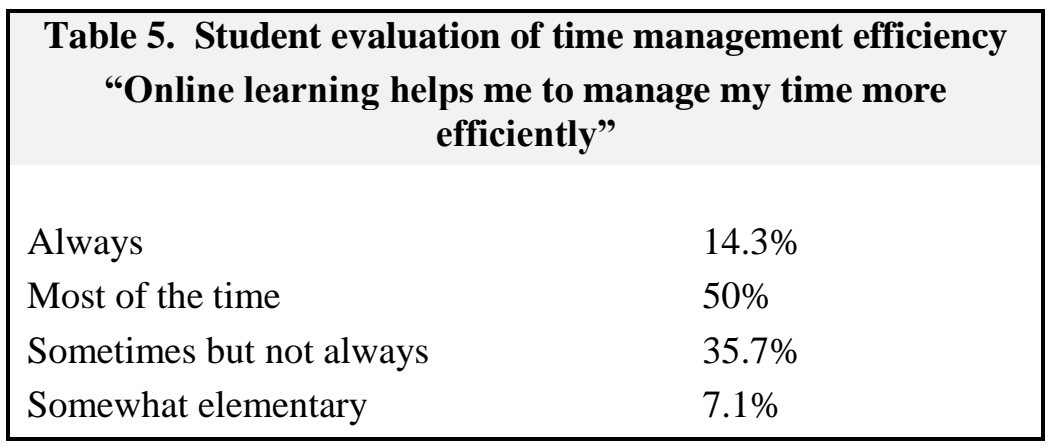

Table 5. Student evaluation of time management efficiency

"Online learning helps me to manage my time more efficiently"

A qualitative follow-up of this question was presented during the student interviews. Two students agreed that learning online is not for every student, but is for those who know how to manage their time properly and are able to efficiently combine work and study. For other students, being able to access the course content online enabled them to finish the course faster than planned in the academic calendar, "I was able to complete my coursework in one month instead of three. This was fantastic!"

With regard to the online course workloads, only two students stated that the online course was heavier compared with the classroom (face-to-face) workload. The majority of the research population (42.9\%) indicated that the course was lighter, and $42.9 \%$ felt the workload in the online course-work was about the same in relation to a classroom based course.

\begin{tabular}{|l|}
\hline \multicolumn{2}{|c|}{ Table 6. Student evaluation of course workload } \\
(Online-F2F comparison)
\end{tabular}

Table 6. Student evaluation of course workload

(Online-F2F comparison)

In the current fiscally challenging times, a very important issue for the survey was to analyze if students were able to combine work with study. Forty two percent of students said they were able to do both activities all the time, 25\% stated they combined work and study most of the time, and 25\% said they combined both activities only some of the time. One student reported that they did not combine working and learning.

The last two questions gathered students' information regarding their online experience and their willingness to take another course online. Responses in the likert scale tended to be in the middle as the majority of the students stated learning online was a good experience most of the time $(50 \%)$ or some of the time (21.4\%). Two students did not find the experience a positive one. 


\begin{tabular}{|ll|}
\hline \multicolumn{2}{|c|}{ Table 7. Learning online was a good experience } \\
& \\
All the time & $14.3 \%$ \\
Most of the time & $50 \%$ \\
Some of the time & $21.4 \%$ \\
None of the time & $14.3 \%$ \\
\hline
\end{tabular}

Table 7. Learning online was a good experience

A qualitative follow up on this issue showed that the time students spent in the workshop (or face-to-face lab) was very valuable for them. They were grateful that the instructor was always available to answer questions in the lab, and that they could practice immediately what they had learned from the online materials.

Table 8 presents students' verbatim opinions on how their role has changed when learning online. As with students at the Cleveland et al research project [1], students in this research also underlined the changes they needed to make to become efficient online learners. It is important to underline the fact that students assumed they needed to play a new role, leaving behind the 'demanding', 'passive recipient of information" that face-to-face learning implies, and embracing a more active, knowledge seeker function that the online environment requests from them.

\begin{tabular}{|l|l|}
\hline Interaction & $\begin{array}{l}\text { It was great to be able to ask questions to my instructor outside the lab time. He } \\
\text { was available almost } 24 \text { hours a day, and that made me feel confident with what } \\
\text { I needed to learn. }\end{array}$ \\
\hline $\begin{array}{l}\text { Instructor } \\
\text { Role }\end{array}$ & $\begin{array}{l}\text { I found the instructor was not there to tell me how to learn the theory but just to } \\
\text { guide me as I explored the course on my own. This saved me lots of time and } \\
\text { allowed me to learn at my own pace. }\end{array}$ \\
\hline Self-identity & $\begin{array}{l}\text { Accessing the course materials online made me realize that I was the only one } \\
\text { responsible of my learning, and that I needed to develop new strategies to be } \\
\text { efficient with my time. }\end{array}$ \\
\hline $\begin{array}{l}\text { Course } \\
\text { Design }\end{array}$ & $\begin{array}{l}\text { The course graphics helped me to understand the processes explained in the } \\
\text { theory. I noticed some of them could have been clearer, but they were just good. }\end{array}$ \\
\hline Technology & $\begin{array}{l}\text { I never thought learning online was going to be fun. Technology made possible } \\
\text { for me the combination of work and studying. }\end{array}$ \\
\hline
\end{tabular}

Table 8: Students' adjustments and interactions with instructors online, verbatim comments

Table 9 presents verbatim instructors' view of their role transformation. For all the instructors involved in the research, teaching online was not an easy task, but invited them to change the way they interacted with students (and with course developers) as it challenged them to radically transform the way they taught.

\begin{tabular}{|l|l|}
\hline Interaction & $\begin{array}{l}\text { Every time I go to my computer I know my students are there, waiting to hear } \\
\text { from me. And I know this interaction with them is not restricted to the lab } \\
\text { hours, but allows me to contact them whenever I need to, or whenever they } \\
\text { have a problem. I like this. }\end{array}$ \\
\hline Instructor Role & $\begin{array}{l}\text { I have noticed that with my course being online, my role as an instructor has } \\
\text { also changed. My students feel free to approach me (using e-mail mostly) and } \\
\text { ask me for feedback or direction. It is no longer me who tells them what to } \\
\text { learn, or how to learn; now I have become more a guide than a leader. }\end{array}$ \\
\hline Course Design & $\begin{array}{l}\text { At the beginning, as we build the online component of the course, we were } \\
\text { invited as the "subject matter experts." We did lots of work with instructional } \\
\text { designers and the multimedia team. At the end, it was amazing how much we }\end{array}$ \\
\hline
\end{tabular}




\begin{tabular}{|l|l|}
\hline & $\begin{array}{l}\text { learn from our colleagues who were also active participants of the course re- } \\
\text { design. }\end{array}$ \\
\hline Technology & $\begin{array}{l}\text { When we started to teach this course online, we were all very suspicious about } \\
\text { using technology to teach 'hands-on' skills. But as we saw the positive } \\
\text { reaction of students to the technology component of the course, and as we } \\
\text { proved how students were very successfully completing their quizzes and } \\
\text { exams online, we realized how much our teaching was transformed, in positive } \\
\text { way, by using technology. }\end{array}$ \\
\hline
\end{tabular}

Table 9: Instructors' role when teaching online, verbatim comments

\section{Instructor-student interactions}

An important factor to analyze in this research was the impact online learning had on instructor-student interaction both inside and outside the lab. According to Collis and Moonen [33], in order to use technologies for teaching and learning, universities have to transform themselves in a number of areas, including the interaction between students and instructors and the ways in which students' access knowledge.

For $57.1 \%$ of the students in the research, the online course provided them with a variety of opportunities to interact with the instructor always or most of the time. The majority of the students $(71.5 \%)$ found that directions for contacting the instructor were clear and specific always or most of the time.

\begin{tabular}{|c|c|}
\hline \multicolumn{2}{|c|}{$\begin{array}{l}\text { Table 10. Students-instructor interaction } \\
\text { "The course provided you with opportunities to interact with } \\
\text { your instructor" }\end{array}$} \\
\hline Yes, always & $21.4 \%$ \\
\hline Most of the time & $35.7 \%$ \\
\hline Some times & $28.6 \%$ \\
\hline No & $14.3 \%$ \\
\hline
\end{tabular}

Table 10. Students-instructor interaction

“The course provided you with opportunities to interact with your instructor"

\begin{tabular}{|l|}
\hline \multicolumn{2}{|c|}{ Table 11. Students-instructor interaction } \\
"Directions for contacting my instructor were clear and \\
specific"
\end{tabular}

Table 11. Students-instructor interaction

"Directions for contacting my instructor were clear and specific"

During the interviews, students were asked about the interaction they had with the online instructor and most of them agreed that having previous knowledge of the workshop (lab) procedures allowed them to reduce the questions to the instructors inside the lab so that the instructors could focus more on those students who had difficulty with learning the procedure. As one student expressed it: "Online materials allowed us to answer our own questions and therefore reduce the demands on the instructor."

These findings concur with what is stated in the literature with regard to the role that information 
technologies play in supporting interaction between students and instructors [37, 38, 35]. For example, Moller [38] remarks that when using technologies to interact with their instructors, students feel they are more involved and that they have learned more.

Instructors played a crucial role in supporting the interaction with students learning online. When interviewed, they stated that they motivated the students to be critical and analytical with what they were learning online. The use of technologies to facilitate instructor-student interaction depends on the instructors' input and attitude towards the students, as well as the students' disposition and skill in using the technologies.

Figure 2 below shows how the interaction between instructors and learners is affected by the use of online technologies (online content, forums, quizzes, etc.)

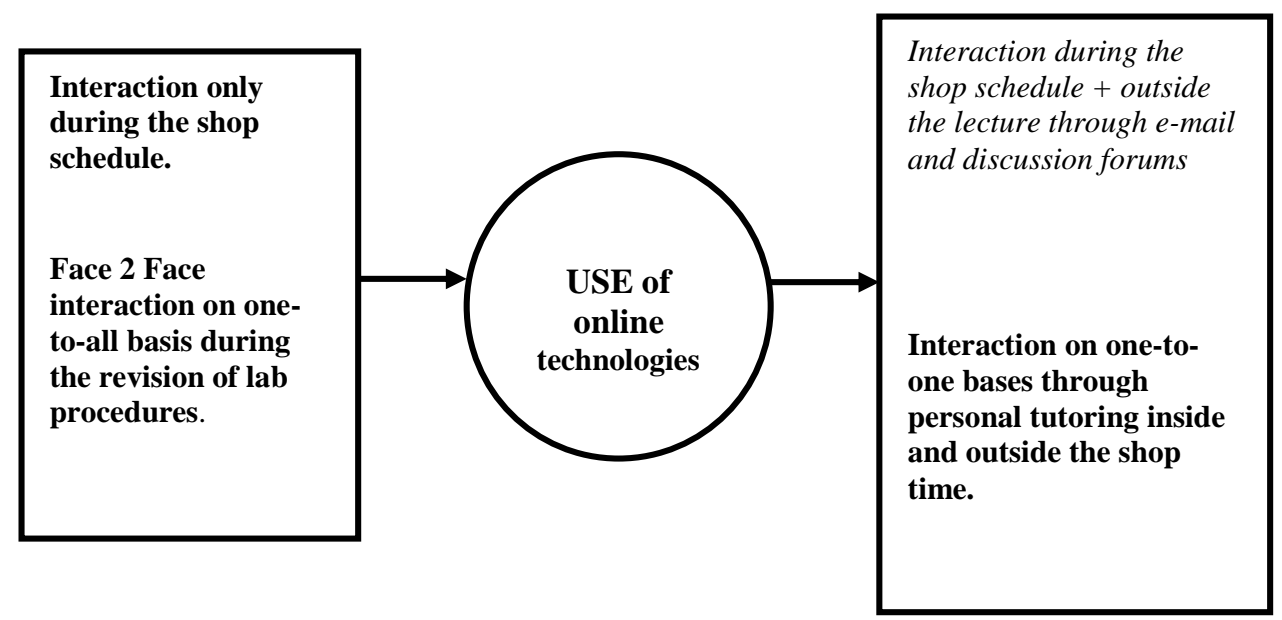

Figure 2. A. Before using online technologies

B. After using online technologies

\section{E. Instructor's perception of role change after the use of online content}

Within the framework of this research, it was clear that instructors played a crucial role in bringing online technologies to their teaching experience. Instructors interviewed for this research stressed the fact that the changes in students' learning did not come only from the use of the online materials, but from their use of different learning techniques. The fact that they knew that their students were familiar with the content review in the lab allowed instructors to let the students help each other solve problems in a collaborative way. Furthermore, instead of lecturing, instructors developed a 'problem based' approach where students in the lab came to them only if they were not able to solve a particular problem on their own.

Instructors' pedagogical views are decisive when they use new technologies in teaching. For example, Bates [39] underlines that new technologies need different teaching approaches and an understanding of the teaching process itself. The application of new pedagogical models has resulted in an ideological shift in the relationship between instructors and students. In this research, the application of a new pedagogical framework was crucial for the success of the use online learning technologies inside and outside the workshop (lab).

One instructor in the interview emphasized the fact that it was their personal challenge to use innovative pedagogical techniques that motivated them towards the use of online learning materials. Students benefit from their instructors' application of innovative pedagogical techniques which prepared them for the workshop (lab): "My challenge is more related to an innovative pedagogic practice, not to the use online curricula." 


\section{CONCLUSIONS, RESEARCH LIMITATIONS AND FURTHER RESEARCH}

Learners' and instructors' characteristics and requirements of online learning are not merely a matter of comfort or student satisfaction. They have practical learning implications and demand the transformation of institutional policies as well. Those policies should encourage faculty to embrace a new role as they transform the role of 'subject matter experts' into a guidance or facilitator function.

Findings in this research support the premise that students experience a dynamic adjustment to the role of online learner, made up of particular ways of behaving, acting and interacting [40, 41]. As the role of the online learner is still undefined, students grapple with requirements, looking to their own reasoning, other students, and the instructor for direction about the right things to do. Adjustments occur in multiple areas as described above, and each of these areas is both constrained and enabled by course design, technology, the instructor, personal self-identity, and the interaction within the community.

Findings in this research support what Meyer et al. [42] found in their research on retention and engagement in an online program. What Mayer et al identified as instructors' support for 'social presence' in an online course, was key to students in this research, and in their engagement to the course capabilities.

Furthermore, the research findings determined that motivation (student engagement) is an important factor for students to be able to review supporting course materials available online. These findings are similar to research carried out in the United Kingdom and published by BECTA (British Educational Communications and Technology Agency) in 2007, where student motivation was a determining factor for the successful use of Web 2.0 technologies.

Evidence supports the premise that the instructors' role is also radically transformed as they interact with students online, and that this transformation requires an adjustment process, consistent with previous findings [43]. Professional development opportunities for instructors should focus on techniques for easing learner adjustment to the online learning environment. Instructors should learn to recognize indicators of adjustment and be prepared to suggest appropriate support services if required.

The provision of ample opportunity for those instructors or students who are unfamiliar with the technology to gain skills and feel comfortable is also a requirement. An orientation session moderated by experienced online learners and facilitators well in advance of the course start date would be highly valuable.

Institutions moving to online delivery should include greater instructor involvement at the beginning of introductory level courses, but judiciously thereafter. This will ease the adjustment for first-time online learners as they assume greater responsibility for meeting learning outcomes, gain comfort in contributing to discussions often dominated by more experienced online learners, and become more confident in their new role without the immediate feedback from the instructor that occurs in the face-to-face classroom. Too much online intervention by the instructor can be intimidating and may decrease engagement.

Changed practice implies role adjustment for the instructors as well as the learners. Professional development activities that focus on the affective components of course delivery will enable instructors to ease the adjustment of the learners to online learning, as well as increase their own comfort level and effectiveness.

\section{LIMITATIONS}

Participants in this study were new to online learning, but they were not new to post-secondary studies. The adjustment to online learning would occur in conjunction with students' skills training; this needs to be considered in the interpretation of findings. In addition, students registered in this online (blended) course were chosen from a pool of apprentice students based on their high marks in previous courses and on their academic accomplishments (such as excellent academic behavior, responsibility, etc.).These factors may have affected the adjustment process and student response to it. 


\section{FUTURE RESEARCH}

This research will need to be replicated in other contexts at other post-secondary institutions in order to determine the efficiency of online learning to support the interaction between instructors and students. Further research will clarify the stages of adjustment for first-time online learners, and online instructors, and similarly for experienced online learners each time they begin a new course. Challenges and appropriate interventions in each of social and academic contexts must be made explicit through research. These responses will ultimately identify what must be in place to ensure complete and competent engagement for online students. It is this latter understanding that is a critical conclusion to this work on learner and instructor adjustments in online environments.

\section{ABOUT THE AUTHORS}

Martha Burkle holds a $\mathrm{PhD}$ on Technology Policies and Higher Education from the University of Sussex in the United Kingdom. She currently works as a Research Associate for the NSERC/iCORE Research Chair on Adaptivity and Personalization in Informatics Project, and as an Instructor for the Centre of Distance Education at Athabasca University. Her work has been published in numerous international journals, including the Harvard Journal of Computers and Healthcare and the Emerald Journal of Education and Training. She was awarded the prestigious Ford-McArthur scholarship for her $\mathrm{PhD}$ thesis in 2002. Dr. Burkle is the Associate Editor of the Canadian Journal of Learning Technologies (CJLT) and serves as an editorial board member of a number of journals, including the International Review of Research in Open and Distance Learning, the Journal of Educational Technology \& Society, and the University \& Knowledge Society Journal. An active member of the Calgary Centre of Innovation (http:/www.thecis.ca/), and a Research Fellow for Athabasca's TEKRI Institute (https://tekri.athabascau.ca/), she pioneered the analysis of the impact of technologies for learning in the development world.

Martha Cleveland-Innes is Professor and Chair in the Center for Distance Education at Athabasca University in Alberta, Canada. Dr. Cleveland-Innes teaches Research Methods and Leadership in the graduate programs of this department. Martha has received awards for her work on the student experience in online environments and holds a major research grant through the Canadian Social Sciences and Humanities Research Council. In 2011 she received the Craig Cunningham Memorial Award for Teaching Excellence and in 2009 she received the President's Award for Research and Scholarly Excellence from Athabasca University. She is currently Guest Professor of Education Media Technology at The Royal Institute of Technology in Stockholm, Sweden. Her work is well published in academic journals in North America and Europe. Current research interests are in the areas of leadership in open and distance higher education, online teaching and learning and the effects of emotion on learning.

\section{REFERENCES}

1. Cleveland-Innes, M., Garrison, R., \& Kinsel, E. The Role of Learner in an Online Community of Inquiry: Responding to the Challenges of First-Time Online Learners. In N. Karacapilidis (Ed.), Solutions and Innovations in Web-Based Technologies for Augmented Learning: Improved Platforms, Tools, and Applications (pp. 1-14). Hershey, PA: Information Science Reference, 2009

2. Allen, I.E., \& Seaman, J. Entering the mainstream: The quality and extent of online education in the United States, 2003 and 2004. Sloan-C/Babson, 2004.

http://www.sloan-c.org/resources/entering_mainstream.pdf

3. Wilson, D., Allen, I.E., Varnhagen, S., Krupa, E., Kasprzak, S., Hunting, V. \& Taylor, A. Instructors' adaptation to online graduate education in health promotion: A qualitative study. Journal of Distance Education, 18 (2), 1-15. (2003)

4. Garrison, D.R., Anderson, T., \& Archer, W. Critical inquiry in a text-based environment: Computer conferencing in higher education. Internet and Higher Education, 11(2), 1-14. (2000). 
5. Blau, J.R. \& Goodman, N., eds. Social roles \& social institutions. New Brunswick: Transaction Publishers, 1995.

6. Turner, J. Role change. Annual Review of Sociology, 16, 87-110 (1990).

7. Kopp, S. F. The role of self-esteem. LukeNotes, 4(2), 2000. http://www.sli.org/page80.html

8. Katz, D., \& Kahn, R. The social psychology of organizations. New York: Wiley, 1978.

9. Kendall, D., Murray, J., \& Linden, R. Sociology in our times. (2nd ed.). Ontario: Nelson Thompson Learning, 2000.

10. Kanwar, M. \& Swenson, D. Canadian Sociology. Iowa: Kendall/Hunt Publishing Company, 2000, p. 397.

11. McLuhan, M. Understanding media: The extensions of man. Cambridge: The MIT Press, 1995.

12. Knuttila, M. Introducing sociology: A critical perspective. Don Mills, Ontario: Oxford, 2002.

13. Collier, P. A differentiated model of role identity acquisition. Symbolic Interactionist, 24(2), 217 235. 2001.

14. Garrison, D.R., \& Cleveland-Innes, M. Critical factors in student satisfaction and success: Facilitating student role adjustment in online communities of inquiry. In Elements of Quality Online Education: Into the Mainstream, Vol 4 in the Sloan-C Series, J. Bourne and J. Moore (Eds.), 29-38. Needham, MA: Sloan-C, 2003

15. Prensky, M. Digital Natives, Digital Immigrants. On the Horizon (MCB University Press, 9 (5), October, 2001. http://helpdesk.muscatine.k12.ia.us/external/MPrensky.pdf

16. Gibson, T.; Koontz, D. \& Van Den Hende, M. The Digital Generation: Teaching to a Population that speaks entirely a new language. Paper presented at the Chair Academy, April 1-4. Denver (USA). (2008). http://david.koontz.name/digital/Presentation files/the digital generation.pdf

17. Wesch, M. A. Vision of Students Today. YouTube Video, Kansas State Univeresity, 2007. www.youtube.com/watch? $=$ dGCJ46vyR9o

18. Jukes, I. \& Dosaj, A. Understanding Digital Kids: teaching and learning in the new digital landscape. The InfoSavvy Group, 2004.

19. Toledo, C. Digital Culture: Immigrants and Tourists. Responding to the Natives' Drumbeat. International Journal of Teaching and Learning in Higher Education, 19 (1); 84-92, 2007. www.isetl.org/ijtlhe/pdf/IJTLHE152.pdf

20. Oblinger, D. Educating the Net Generation. Research Report. EDUCAUSE, 2009. www.educause.edu/educatingthenetgen

21. Oliver, B. \& Goerke, V. Australian Undergraduates' use and Ownership of Emerging Technologies: Implications and Opportunities for Creating Engaging Learning Experiences for the Net Generation. Australian Journal of Educational Technology, 23 (2); 171-186, 2007. www.ascilite.org.au/ajet/ajet23/oliver.html

22. Creanor, L., Trinder, K., Gowan, D., Howells, C. LEX The Learner Experience of e-learning. Final Report. Glasgow Caledonian University, August 2006. www.jisc.ac.uk/uploaded_documents/LEX\%Final\%Report_August06.pdf

23. Tapscott, D. Grown up digital. New York: McGraw-Hill, 2008.

24. Anderson, P. What is Web 2.0? Ideas, Technologies and Implications for Education. JISC Technology and Standards Watch, 2007. www.jisc.ac.uk/media/documents/techwatch/tsw0701b.pdf

25. Evans, T. \& Nation, D. Changing University Teaching. Reflection on Creating Educational Technologies. London: Routledge, 2000.

26. Deal, A. Podcasting. A Teaching with Technology. White Paper. Office of Technology for Education \& Eberly Center for Teaching Excellence. Carnegie Mellon University, Pittsburgh, PA, 2007.

27. Daniels, J.S. Mega Universities and Knowledge Media: Technology strategies for Higher Education. London: Routledge, 1998.

28. Mason, R. Using Communications Media in Open and Flexible learning. London: Kogan Page, 1998.

29. Laurillard, D. Rethinking University Teaching. London: Routledge, 2002. 
30. Sfard, A. On two Metaphors for Learning and the Dangers of Choosing Just One'. Educational Researcher, 27 (2); 4-13, 1998.

31. Burkle, M. The Impact of Information and Communication Technologies on Higher Education Systems. University of Sussex, Falmer, Sussex, UK. Unpublished doctoral dissertation, 2003.

32. Perry, D. Hand-held computers (PDAs) in Schools. Coventry, UK: Becta, 2003.

33. Collis, B. \& Moonen, J. Flexible Learning in a Digital World. London: Kogan Page, 2001.

34. Sloman, M. The e-learning Revolution. London: Chartered Institute of Personnel and Development, 2001.

35. Holley, D. \& Haynes, R. The INcoterms Challenge: Using Multimedia to Engage Learners. Education and Training, 45 (7); 392-401. 2003.

36. Harasim, L. Online Education: Perspectives on a New Environment. Ontario: Praeger Publishers, 1990.

37. Hiltz, S.R. Evaluating the virtual classroom. In Harasim, L. (Ed.). Online Education: Perspectives on a new environment. New York: Praeger Publishers, 1990.

38. Moller, L. Designing Communities of Learners for Asynchronous Distance Education. Educational technology research and development, 46, (1); 115-122, 1998.

39. Bates, A. Managing Technological Change; Strategies for Colleges and University Leaders. San Francisco, CA: Jossey-Bass Publishers, 2000.

40. Knuttila, M. Introducing sociology: A critical perspective. Don Mills, Ontario: Oxford University Press, 2002.

41. Burkle, M. e-learning Challenges for Polytechnic Institutions: Bringing mobility to hands-on learning. In Ebner \& Schieffner (Eds.). Looking towards the Future of Technology enhanced Education. IGI Global, 2010.

42. Meyer, K, Bruwelheide, J., Poulin, R. Why they stayed near-perfect retention in an online certification program in Library Media. Journal of Asynchronous Learning Networks (JALN) Volume 10, Issue 4 - December 2006.

43. Cleveland-Innes, M., Sangra-Morer, A. \& Garrison, D. R. . The art of teaching in an online community of inquiry: The online teacher as bricoleur. 5th European Distance Education Network Research Workshop, Paris, France, 2008. 